and is thus the less sensitive of the two instruments. An examination in detail of these curves shows that the temperature was at its lowest about eight minutes after the middle of the eclipse, and began to rise rapidly as the eclipsed portions of the sun became less. The highest reading with the black bulb thermo. meter before the eclipse began was $63^{\circ} \%$, the lowest during eclipse being $35^{\circ} 7$, showing a fall of $28^{\circ}$. With the white bulb the corresponding readings were $15^{\circ} .6$ and $3^{\circ}$ respectively, showing a drop of $12^{\circ} 6$.

\section{DOMENICO CIRILLO AND THE CHEMICAL ACTION OF LIGHT IN CONNECTION WITH VEGETABLE IRRITABILITY.}

O NE hundred and one years ago, on October 29, I799, Domenico Cirillo, the Neapolitan Linnxus, was hanged on the market-place of Naples, together with some of the noblest among Italian men of letters and science. It is especially fitting to remember Cirillo in England, the country which he visited and where he had many friends, and for the literature and science of which he showed a special predilection-a country which unfortunately had such a fatal influence upon his destiny.

The Cirillos of Grumo, a village of Terra di Lavoro, were a family of doctors, naturalists and artists. At the beginning of the eighteenth century Nicola Cirillo was famed, both as a physician and a botanist. Following the best traditions of Neapolitan science, the traditions of Pinelli, of Imperato, and of Maranta, Nicola Cirilloinstituted a private botanical garden, the only one then existing in Naples. In 1718 he became a Fellow of the Royal Society of London, and in connection with this Society, then presided over by Sir Isaac Newton, Nicola Cirillo began to collect meteorological data on the climate of Naples. After his death, in 1734 , his botanical garden and his collections, together with the famous herbarium of Ferrante Imperato, were preserved, and the garden improved with the more recent systems of classification by Sante Cirillo, painter and naturalist, whose house became a centre of the learning and culture of Naples. ${ }^{1}$

Iomenico Cirillo was born in 1739 , and so profited by the education and influence of Sante, his uncle, of Nicola Capasso, Francesco Serao, and of other teachers, that at the age of twenty-one, in 1760 , he successfully competed for the chair of botany in the University of Naples. Domenico Cirillo, indeed, followed in the track of Nicola, and soon became known both as a botanist and as a physician. In numerous botanical excursions he visited the greater part of the provinces of Southern Italy and Sicily; and he was the first to organise in this country a regular botanical survey, sending out pupils and assistants to collect in different provinces. Thus not only many rare plants were described in his "Fascicoli Plantarum rariorum Regni Napolitani," begun in 1788 , but several new species were discovered. At present, in the Italian flora, about thirteen species of phanerogams are retained as first discovered and described by Cirillo.

That period, when men worked under the spell of Linnæus, was a time of great botanical fervour, of furore botanico to use Cirillo's expression, in the collecting and investigating of plants. Of Cirillo's early connection with Linn:eus, botanists are still reminded by the name of the Cyrillae, which the great Swede dedicated to his young Neapolitan correspondent. Indeed, the devotion of Cirillo for Linnieus was so great that, following the impulse of his enthusiastic nature, he raised a monument to him in the old botanical garden of the Cirillo family.

Induced by Lady Walpole, Cirillo visited France and

1 Ferrante Imperato, whose herbarium was preserved in the Cirillo col lections, lived at the end of the sixteenth century. In writing his "Historia naturale," printed in Naples in 1599, I mperato put together a museun which soon teecame known in Europe; for besides having for fellow-worker in Naples B. Maranta and Fabio Colonna, Imperato corresponded with P. A. Mattioli, Gaspard Bauhin, Ulisse Aldovrandi, A Ielchiorre Guilandino. and others of the foremost hotanists of the time. His herbarium is said to have been composed of eighty volumes. The museum of Imperato got dispersed during the plague of 1656 , and Nicola Cirillo eventually obtained possession of only nine volumes. After the sacking of I) omenico Cirillo's house in 1799 , one volume only of the Imperato herbarium was saved, and is now in the Biblioteca Nazionale of Naples. It contains 440 dried plants, i.e. about one-seventh of all the plants identified in the days of Imperato and Bauhin. 'Ihis herbarium, together with the herbarium of Cesalpino, is among the rarest of botanical relics.

$O f$ the herbarium of Domenico Cirillo a small remaining portion is now preserved in the botanical museum of the Arricultural College of Portici, in the care of Prof. O. Comes.

No. I6 I 8 , voL. 63]
England, becoming connected with D'Alembert, Diderot, Nollet, Buffon, Franklin, Sir John Pringle, and especially with IVilliam and John IIunter. He was elected a Fellow of the Royal Society. In $177 \mathrm{I}$ he published in the Philosophical Transuctions an account of the Manna Tree of Calabria, Sicily and Monte, Gargano, describing the method of extracting the manna. The Philosophical Transactions also contain his observations, made near Taranto, on the effect of the tarantola bite ; Cirillo confirms what Serao, in $\mathbf{1 7 4 2}$, had already written on Tarantism, dispelling the absurd superstition of the musiccure supposed to be effected by dancing the Tarantella. $\mathrm{He}$ observes how in Sicily the tarantola is never dangerous, and the music-cure is unknown. ${ }^{1}$

In the latter part of the eighteenth century, while the Neapolitan kingdom was freeing itself more and more from the baneful Spanish influence, during the early years of the reign of Ferdinand IV. and Maria Carolina of Austria, a spirit of reform and progress had risen in South Italy, and a new impulse was given to research in natural sciences. In medicine, after Francesco Serao and Domenico Cotugno, Cirillo rose above the rest. The researches and teaching of Giovanni Maria Della Torre and of Cirillo opened a new field to the Neapolitan naturalists in microscopical investigations. Andraround Cirillo, again, a ne:w school of botanists and zoologists and of chemical investigators arose, among whom we may record the names of Filippo Cavolini, Vincenzo Briganti, Gactano Nicodemi, Antonio Barba, Saverio Macrî, Antonio Fasano, Nicola Pacifico, Vincenzo P'etagna, Matteo Tondi, Nicola Andria, Vincenzo Comi. The discoveries of Alberto Furtis in 1783 , near Molfetta, where he observed the richness of the soil in nitrates, led to investigations in Naples on the origin of nitre, in which Fortis himself, Melchiorre Delfico, Giuseppe Giovene, Ciuseppe Vairo and Zimmermann were chiefly engaged. In geological and mineralogical research Giov. M. Della Torre took the lead, and with him, or shortly after him, worked Ascanio Filomarino duca della Torre, Domenico Salsano, Gius. Gioeni, Gaetano De Bottis, Luigi De Curtis, Vincenzo Santoli, Jomenico Tata, Scipione Breislak, Camillo Pellegrini. In I 788 Lazzaro Spallanzani began his tour to the volcanic regions of Southern Italy and Sicily. In those days Sir William Hamilton, during the many years of his residence in Naples, collected information on the Phlegrean Ficlds, while Ascanio Filomarino was forming his Vesuvian Museum, destined to so short an existence; for the museum and all the other scientific collections in the Filomarino Palace were destroyed in January I799, when the unfortunate duke and his brother, Clemente Filomarino, the poet (the translator of Young's poems), were burnt as Jacobins by the infuriated Royalist mob. ${ }^{2}$

During this same period some of the more important foreign works were translated into Italian and published in Naples; such as the works of Stephen Hales, of Priestley, Linnizus, and the Agricultural Encyclopedia of Kozier. ${ }^{3}$

Omitting here all mention of his medical and other publica. tions, Cirillo's chief works on botany and entomology were the following :- "Tabulx botanicie elementares," 1773 ; "De essentialibus nonullarum plantarum characteribus," I 784 ; "Entomologia Neap. Specimen primum," 1787-1790; "De Cypero Papyro," 1787 , reedited at Parma in 1796 ; "Fundamenta botanica, sive philosophix botanicie explicatio," I 787 ; "Plantarum rariorum Regni Neapolitani," fasc. i. I 788, fasc. ii. 1793; "Discorsi Accademici," 1789 , re-edited in 1799.

In the field of vegetable physiology, the discoveries of Cirillo on the irritability of plants are noteworthy. In that field, together with his contemporary, G. B. Dal Covolo, Cirillo is the

1 The music-cure for the tarantola bite is still practised by peasants, especially women, in some parts of the province of Lecce and in Calabria. In Cirillo's days the belief in the dangerous and strange effects of the bite of the tarantola was held cven by persons high in authority. See Andrea Pigonati, "Sul Tarantismo," Opuscoli Scelti ii. (Milano, I779). Compare Franc. Serao, "Della Tarantola o sia Falangio di Puglia" (Napoli, 1742). 2 Duca della Torre, "Iescrizione del Gabinetto Vesuviano da lui posseduto" (Napoli, r796, 2da ed.)

3 The works of Hales were translated by a lady, Maria Ardinghelli; St. Hales, "Statica dei Vegetabili ed Analisi dell' $\Delta$ ria, trad. dall' Inglese con varie annotazioni da M. A. Ardinghelli " (Napoli, I756).

St. Hales, "Emastatica, ossia Statica degli Animali. Esperienze idrau. liche facte sugli animali viventi" (Napoli, 1776).

Gius. Priestley, "Sperienze ed Osservazioni sopra diverse Specie di aria, rad. dall' Inglese" (Napoli, 1754).

The translation of Rozier's Encyclopadia was begun in 1783 , and was due to the Societs Letteraria di Napoli, of which Cirillo was one of the leading members.

Vircenzo Petagna began editing the "Species Plantarum" of Linnæus. 
direct successor of his celebrated compatriot, Alfonso Borelli, who, in 1653, discovered in Naples the irritability of the anthers of Centaurea, and of other Cynarex. In his essay, "Del Moto e della Irritabilità dei Vegetabili," published in 1789, Cirilio briefly describes what was then known of the sleep of plants, of the movements of the leaf blade of Dionoea muscipula, and of the fly-trap concealed in the flowers of Aposynum androsaemifolizm, a plant then lately studied by Francesco Bartolozzi in Milan. ${ }^{1}$ Cirillo quotes Linnzeus' description of the movements of the Hedysarum gyrans, first discovered by Pohl in 1779 . After describing the irritability of the stamens of the Cynarea, the gradual sensitiveness of the flowers of Verbascum to shocks, and the recent observations of Duhamel and of others on the stamens of Berberis, and of Parietaris officinale, Cirillo goes on to describe his own discoveries of irritability in Forsckohlca tenaizsima, and in the common nettle, Urtica dioica. "The study of the very complex fructification of the first plant (Firsckohlea) having revealed to me the spiral structure of the filaments, similar to those of Parietaria, I was led to verify whether these filaments also possessed irritability. It is of great interest to observe in the nettle, during the warmer morning hours, how the male flowers open abruptly, and suddenly burst open their well-closed anthers, that eject abundant fertilising dust."

These observations brought Cirillo to believe that the "marvellous irritability of the sensitive plant, as well as the elasticity in the stamens of flowers, must be partly due to the spiral structure of the organs in which the contractions take place, chiefly, however, to the very frequent articulations of which these parts, so mobile and so irritable, are essentially composed."

Hedwig had in these years opened the way to the knowledge of mosses; and Cirillo again observed cases of irritability and elasticity in the capsules of mosses and in the filaments they contain, the articulated structure and the spiral form of which again confirmed his opinion on the mechanism of plant movement. ${ }^{3}$

In studying the sensitive plant, Cirillo points out the enlargement at the insertion of each leaf; and observing what he believed to be a spiral structure within this "tubercle-like body," suspects a connection between the spiral structure and leaf-movement. Comparing the Mimosa pudica with the Mimosa glauca, Cirillo finds that the great difference in their sensitiveness corresponds with the different size and develop. ment of the articulations containing the spiral structure. This spiral structure corresponds, of course, with the fibro-vascular bundle inside the pulvinus, the motor organ, in which, as we now know, the sap tension suddenly sinks at every cause of irritation.

Following the ideas of Haller, the first to have a notion of protoplasm as the physical basis of life, Cirillo believes that the seat of irritability and of life, both in animals and in plants, must be in mucilaginous substances. Thus he points out that in plants "glutinous principles" are commonly met with which must be the seat of motion, of contraction, and of irritability. Curiously enough, as an example of this glutinous principle, Cirillo gives the "elastic resin now used so extensively" extracted from the sap of Jalropha elastica, and existing, as he observes, in many other plants. In that time, when only impure rubber was in commerce, it had been observed that this substance, besides strongly-smelling empyrheumatic products, yiclded ammonia hy distillation; it was therefore generally considered of the same nature as glutinous animal substances."

1 Fr. Bartolozzi, "Sopra la qualiı che hanno fiori della pienta detta A pocynum Androsæmifolium di prendere le mosche, con una osservazion nuova sulla fecondazione delle piante," Opuscoli Scelti ii. (Milano, 1779, p. IO 3 ; and iv. $(78 \mathrm{r}$, p. 73$)$

2 Besides G. B. Dal Covolo, "Niscorso delia irritabilità di alcuni fiori nuovamente scoperta" (Firenze, $176_{4}$ ), compare with the observations of contemporary butanists-G. E. Smith in Fingland, and Des Funtaines in France. An abridgment of these olsservations was published in Italian at Milan: 1)es Fontaines, "Sull' Irritabilita degli organi sessuali di molt piante," Opuscoli Scelti x. 1787, p 4 i 7 ; G. G. Smith, "Sopra la irritabilit dei vegetabili," Op. Scelt. xi. 1788, p. 379.

3 See also Antonio Barba, "Osservazioni sopra la generazione de Muschi," Op. Scclt. v. $17 \delta_{2}$, p. 123. Barba was a pupil of Cirillo and of Della Torre.

4 See also Andrea Comparetti, "Nouvelles Recherches sur la Structure organisée relativement a la cause des mouves Rech de la sensitive communture (ifim. Acad. te Turin, r79o).

(M. 1 it is interesting to remember that in those days, in London, Tiberio Cavallo was first beginning to prepare india-rubier tubing for scientific Cavallo was first beginning to prepare india-rubier tubing for scientific use, the tubes being made rrom an ethereal solution of the india-rubber. See Faujas St. Fond, "Su alcune arti utili, tratte da un viagg
terra, in Scoria, e alle Isole Ebridi," Op. Scelt. $x \times$. r 797, p. 60.

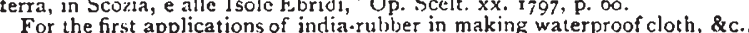
For the first applications of india-rubter in making waterproof cloth, \&c.,
and for a description of Grossard's method of making india-rubber tubes, sec Cervantes, "Resina Elastica," Op Scelt. xxi. 1798, p. 97. NO. 1618 , VOL. 637
The researches of IItunter, showing the connection between nerve-action and electricity in the torp:do, and the experiments that Cirillo's friend Italisckhi was making in Naples on the electrical organ of the torpedo, brought Cirillo to believe that there must be some special connection between electricity and the action of nerves, and in general with all manifestations of irrita bility. As is welt known, that was an active period of re. search on the torpedo: suffice it to record the names of Walsh, Pringle, Spallanzani, Soave. At Naples, in 1784 , Domenico Cotugno accidentally received an electric shock in vivisecting a young mouse : this on the eve of I nigi (salvani's discoveries in animal electricity. This was also the period of greater fervour in experimenting upon the influence of electricity on vegetation. These experiments were chiefly carried out by Achard in Germany, Berthelon in France, Toaldo, Gardini and Vassalli in Italy and by Ingen-I Iousz in England. Vassalli and Rossi were soon to show the excitability of the sensitive plant under electric action.

The connection of the shemical action of atmospheric air with respiration, and with all forms of animal and regetable motion, was evidently in the mind of Cirillo. Indeed, for many years scientific research in Italy, both on animal and vegetable life, had been discovering more and more this connection, pre. paring the way to modern knowledge of respiration and of the origin of vital heat and of vital motion.

Fracassati, in 1665 , had observed the change of colour in blood when shaken up in air. The experiments of John Mayow, the pre-discoverer, if the term may be used, of oxygen, were perhaps better known and appreciated in Italy than in England, through Ludovico Barbieri, of Imola, who translated and ex. tended the work of the English chemist. Barbieri observed that the bright colour of arterial blood must be due to impreg. nation with nitro-aierial spirit; and he showed, by experiments on the transfusion of blood into an animal prevented from breathing, the truth of Mayow's teaching, that atmospheric nitro-aerial spirit, fixed in the blond, sustains life and, as in the case of the name, produces heat. Barbieri also taught that the nitro-aerial spirit of the air causes the germination of seeds and sustains the life of plants. ${ }^{2}$

Hales, during the first part of the eighteenth century, had shown how plants suffer when enclosed in gases other than air, as the "air" extracted by distillation from Newcastle coal. Bonnet and Duhamel observed subsequently that leaves perish when covered with oil. But to Buonaventura Corti, the discoverer of protoplasmatic movements in the vegetable cell, is due the first exact proof of respiration in plants. Corti showed, in a series of experiments, that when air is excluded from the vegetable cell all circulation of the cell-sap is arrested: "now that we have shown," he observes, "that the circulation of the sap of the Chara is arrested when in vacuo, we readily understand why all plants perish without air, and why seeds cannot germinate without air, or perish shortly after sprout. ing." 3 In those days, in 1773 , Francesco Cigna, in Turin, was again proving the action of air upon the colour of blood, and the influence of blood upon the properties of air. Cigna's experiments were repeated with greater exactitude, after the discovery of vital air, by Priestley, who showed that vital air, i.c. oxygen, causes the blood to brighten, while its colour deadens in contact with other gases. The discoveries of Priestley were fullowed, in I779, by Adair Crawford's theory and experiments on respiration and animal heat. ${ }^{*}$ According to Crawford, the latent heat of atmcspheric air gradually becomes perceptible as animal heat, while the air absorbed through the lungs gets mixed and retained in the blood, which yields its phlogiston to the atmosphere. Crawford held that vegetable matter is elaborated, and becomes charged with phlogiston, under the action of solar rays; whilst during the combustion of vegetable matter phlogiston is again yielded up to the atmosphere and fire generated, in the same way blood generates heat, while phlogisticating expired air. Vegetables again, growing under the infuence

1 Cotugno's observations on the electrical mouse are described in a letter to Vivenzio. See Tiberio Cavallo, "Teoria e Pratica dell' Elettricita Medica." (Napoli, 1734 , p. I57). This is an Italian translation by Vivenzio the original English work was published by Cavallo in Iondon, in 1780 . 2" "Planta a spiritu nitro-aereo prima vitze stamina suscipit," wrote Barbicri in 1680 . See Salvigni, "Ragionamento sopra alcune dottrine chimiche di Giovanni Mayow e di Ludovico Barbieri" (Bologna, i8 16). $3 \mathrm{~B}$. Corti, "Osservazioni microscopiche sulla fremclla e sulla circolazione del fluid, in una pianta acquajuola" (Lucca, $x 7_{4}, \mathrm{p}$. 19r). 1 An Italian abridgment of Crawford's paper was published very soon
ats after its appearance in England: Adair Craivford, "Sul calore animale e sull' infiammazione dei corpi combustibili," Opuscoli Scelti iii. 1750, p. 73. 
of light, separate phlogiston from the tainted air, and repristinate in the atmosphere the power of generating heat by combustion or by respiration. A cycle of the principles of heat and of phlogiston is thus maintained through atmospheric air between the vegetable and animal kingdoms. Sabstituting the old conception of phlogiston by the modern idea of energy, we pcrceive in Crawford's theory the germ of the theory of the preservation and transformation of energy. Crawford's work prepared the way, as Carradori pointed out in 1792 , to Lavoisier's experiments on recpiration, and for the ready acceptance of his thenry.

In Italy, where the experiments of Marsiglio Landriani, of Pietro Moscati and of Lazzaro Spallanzani, were then showing the influence of different gases on cutaneous respiration, and where Spallanzani was demonstrating the evolution of fixed air even from tissues separated from the living body, and in organisms prevented from absorbing free vital air, the theory of Crawford was readily accepted, and served as a starting-point to the experiments of Michele Rosa in Modena. Rosa, indeed, followed directly in the track opened by Ludovico Barbieri a century before. By a numerous series of experiments in transferring arterial blosd into animals prepared by copious bleeding, and by the different comportment of arterial and venous blood in zacuo, Rosa showed that the vital principlc has its seat chiefly in the blood, and is maintained by the continuous action of atmospheric air during respiration, being due to the same cause that maintains combustion. Rosa's work has not been sufficiently appreciated because of his misapplication of names, and was too soon forgotten in the great light shed by the experi. ments of Lavoisier; but there is no doubt that to Rosa is due the first demonstration of the incorporation of oxygen in the blood, of the special labile condition of its combination, and of the supreme inportance of acration for the vitality of all animal tissues. ${ }^{1}$

When Cirillo wrote his essays, the theories of Crawford and of Rosa were in their bloom, and were warmly espoused by the Neapolitan naturalist. Cirillo believed that all life, animal and vegetable, had its origin in the action of air upon the "glutinous principle," that is, the basis of life in all tissues, and that light, electricity and heat, but especially solar light, are all connected with the quickening of life. like Lavoisier, Cirillo looked upon sunlight as the crigin of all life: "Sunlight," he wrote, "the only, the inexhaustible, primitive and incomprehensible fount that pours heat and motion and life upon our globe."

John Hill, in his letter to Linnzus in 1753, had shown the special connection of light, independently of heat, with the sleep-movements of plants. Priestley's celebrated experiments on the purifying action of vegetation upon air vitiated by respiration, or hy combustion, had been known since 1772 . In 1779 Ingen.Housz pointed out that this action of plant-life is due to sunlight, and only takes place when light acts upon green plants. Cirillo himself must have observed the attraction of lower organisms towards light, similar to those swarm-spore movements that shortly after were first described by (iiuseppe Olivi." "Why," asks Cirillo, "do all polyps love light, so that, on darkening the vase in which they are contained, leaving free only a tiny hole, they all forsake darkness, and throng near the. spot where they can enjoy the immediate action of the solar rays? Why are all marine animals so filled with a luminous vapour, emitting phosphoric light? Why are the most irritable fish phosphorescent and electric? Why do plants, when deprived of solar light, lose colnur, aroma and robustness ?" Cirillo, like most of the writers of his time, was not clear in the distinction between light and heat; but what is predominant in his mind is that all movement, both in animals and in plants, is due to fixation of vital air, to oxidation, and that light therefore, by causing the sleep-movenents in plants, must be connected with some process of oxidation.

While Cirillo was writing, Senebier had alrealy showr. (1788) that the chief action of light in plants is the reverse of oxida. tion, causing the decomposition of carbonic acid and the evolu. tion of oxygen. The importance of this discovery, and the

I Michele Rosa. "I.ettere fisiologiche." 3da ed. ; "Colle usservazioni ed Esperienze sul Sangue fuido e rappreso dal Signor Pietro Moscati," 2 vols. (Napoli, i788).

This edition is dedicated to Domcnico Cirillo. The experiments of Rosa were first published in Vicenza in ${ }^{2} 782$. The experiments of I avoisier on animal respiration, first published in Paris in 1777 , appeared in Italian in 1781 (Opusculi Sicelti is. $178 \mathrm{r}$, p. 133)

Giuseppe Olivi, "I) Delle Conferve irritabili, e del loro movimento di progressione verso la luce, Esame chimico" (Mem. di Mlat. e Fisica della Soc. Italiana, tom. vi. Venezia, 1793).

No. 1618 , voL. 63$]$ mistaken notions about plant-respiration, caused what may be called the minor functions of light in plants to be neglected. Only long after the days of Cirillo and of Senebier, in the latter part of our century, investigations began on the influence of light in respiratory processes: in the decomposition of chlorophyll, in changing the composition of the sap, and the distribution of osmotic tension, and consequently in causing the movement of plant-organs, as in the case of nyctitropic and heliotropic movements. These changes are promoted, as was first shown by Michelangelo Poggioli in 1817, by the more refrangible rays of the spectrum, by those rays, namely, that are specially active in causing the oxidation of organic compounds ard in decomposing silver and other salts.

Cirillo's opinions on the chemical activity of solar rays were due to his own original observations on the chemical action of sunlight upon silver chloride. His experiments were made to test the truth of an assertion by Nicola Andria that certain Ischia waters contained phlogisticated alkali (yellow prussiate), and could consequently produce Prussian bluc." "A curious phenomenon," Cirillo writes, "has been recently ohserved by me whilst analysing the Olnitello water of the Island of Ischia. Investigations of our chemists had brought them to believe that this water contained a phlogisticated alkali, similar to that prepared from the colouring natter of Berlin blue; for, on mixing the water with some luna cornea, or with a solution of silver in nitrous acid, not only was a white substance instantly produced, but after a short time it changet to a very beautiful and dark azure colour. This experiment, seeming to show the existence of a phlogisticated alkali in the Olmitello water, having been accidentally repeated by me towards evening, I observed that the mixture remained white during the whole night, becoming azure only on the following morning, after the rising of the sun. I also noted that the intensity of the azure colour in the sediment increased with the growing intensity of sunlight. These results led me to repeat the experiment while excluding all action of light. To half a glass of Olmitello water $l$ therefore added a few drops of the solution of silver in nitrous acid; and as soon as the white precipitate due to the alkali was formed, I shut the glass in a place utterly impenetrable to light. For many days the precipitate remained white; but on exposure to light it became cerulean in a few mimutes. The same change was observed in a water from Calabria ; for, on treating it as the Olmitello water, it also rendered blue the luna cornea. Also our common ivaters, probably charged with an alkaline earth, undergo the same change. I am aware of what recent writers have said about the repristination of metals ly solar heat; nor do I ignore how with a burning lens the illustrinus Priestley, heating inflammalsle air in contact with minium insicle a glass vessel, was able to repristinate lead. But my experiment will serve at least to correct the error of those who analysed the Olnitello water, believing it to contain a phlogisticated alkali, similar to the Prussian alkali; and secondly; this experiment gives us a sure proof of the energy of solar rays in repristinating metals. These observations, alchough having a distant connection with the novements and irritability of vecetables, are also worthy of record in connection with other comsiderations which I hope shortly to publish."

Cirillo's essay was published, in its first edition, in 1789 , so that the Oimitello experiments must have been made shortly before that year and after Andria's last publication of 1783 . As is well known, the experiments of scheele (not counting the earlier, forgotten experiments of J. H. Schultze in 1727) were published in Swedish in 1777 ; a lirench translation, by I3aron 1)ietrich, of Scheele's treatise on Air and Fire appeared in Faris in $178 \mathrm{1} .2$ Scheele's experiments on luna iormea and other silver salts are quoted and commented upon by Felice Fontana in ${ }_{17} \mathrm{~S}_{3} .^{3}$ Senebier, in 1782 , had been experimenting on the rapidity of action of different lights upon silver chioride." Cirillo therefore ought to have been acquainted with Scheele's experiments, although there is every reason to believe that he, generally so precise in recorcling previous work, was not aware that, only a few years before his own experiments with the Ischia water, the action of light upon silver salts, and especially

I Nicola Andria, "Irattato deile acque minerali." ada ediz (Napoli, $\left.178_{3}\right)$

2 Ch. Giul. Schecle,

Dietrich. (Paris, $178 \mathrm{r}$ ). 3 Felice Fontana, "
Opusc. Scelti vi. $178_{3}$ )

Opusc, Scelti vi. ${ }^{17} \hat{S}_{3}$ ). Jean Senebier, "Mém. physico-chymiques sur l'influence de la Lumière
Solaire, pour modifier les être; des truis régnes de la Nature" (Génève, 1782). 
the action of the more refractive rays of the spectrum, had been demonstrated ard studied by the highest chemical investigator of the time, who had died in 1786 . Cirillo's observations are, however, worth recording, because they were connected in his mind with the action of sunlight in causing movements and irri. tability in vegetable organs.

Other workers in those days were investigating in Italy the chemical action of light ; and their experiments, like those of Cirillo, are also generally forgntten. In 1782 , Alessandro Barca, in Padua, studied the effect of solar rays in accelerating the decomposition of phlogisticated alkali, or yellow prussiate, in the presence of acetic acid. ${ }^{1}$ In 1794, Anton Maria Vassalli, in Turin, in comparing the action of solar and of artificial light. showed that the latter darkens silver salts, causes chlorotic leaves to become green, rouses the sleeping leaves of the sensitive plant, and acts generally in the same manner, although with less intensity, as the light of the sun. Vassalli observed a diminution in weight in the silver chloride darkened by light; he also experimented upon the effect of moonlight upon this salt, and upon vegetation. ${ }^{2}$

The "I)iscorsi Accademici" of Cirillo, in which are the two remarkable essays, "I)el moto e della irritabilità dei vegetabili" and "La cagione della vita," were first published in I 789 , and re-edited in 1799: This sccond edition was the last scientific labour of Cirillo, for in that same year he was overwhelmed in the political storms that swept over Napies. All the writings of Cirillo glow with warm philanthropy and patriotism, and we see in them a constant protest agrainst the prejudices and superstitions then so high in authority in the Neapslitan kingdom. After the cowardly flight of King Ferdinand from Naples in December 1798, leaving the city a prey to royalist anarchy, Cirillo joined with the patriots who favoured the entrance of the French into Naples and the establishment of the Parthenopiran Republic. Pressed by the insistance of his friends, Cirillo accepted the presidency of the legislative body, but during the brief period of his political power he occupied himself mainly in alleviating the growing misery of the people; ab ve all, Cirillo remained the philanthropist and the pbysician rather than the politician. The Republic lasted a few months, sinking finally in the struggle with the brigand hordes of the I Ioly Faith, that through pillare and bloodshed Cardinal Ruffo led from Calabria to Naples. Cirillo was among the many who capitu. lated in the Castles of Naples, nn condition of a free passage to a French port. The sorrowful history of what followed is well known, of how the capitulation was ruthlessly broken when Castles and prisoners were secured. All those who had held office under the Kepublic, or had any direct connection with its government, were condemned to death for high treason. From June 29,1799 , to September I 800 , execution followed execution, until in Naples alone ninety-nine of the foremost men were put to death, besides the many-it is said 300 -executed in the provinces. Domenico Cirillo was hanged on the same day as Mario Pagano and the noet Ignazio Ciaja. "For the dealh of these men all the city mourned," wrote Marinelli, a diarist of the time. Another botanist, Abate Nicola Pacifico, an old man of seventy, companion and fellow. worker of Cirillo, shared his fate on August 20, on the same day when the gifted Fleonora Fonseca Pimentel was delivered to the hangman.

Cirilio's house was pillaged by the mob, and his collections and books, among which was the herbarium of Imperato, were burned or dispersed. "Let the idle and ignorant know that love of humanity, zeal for science, and faithfulness to duty can only be quenched in me with my life"-thus wrote Cirillo in the days of his prosperity, little dreaming of the distant purport of his words. Nobly indecd, when oppression and ignorance prevailed, in the days of suffering and agrony, Cirillo to the very last kept faith to duty and to Fatheriand. ITALO GIGIIOI.I.

\section{METALLIFEROUS DEPOSITS.}

A COURSE of four Cantor Lectures delivered before the Society of Arts by Mr. Bennett II. Brough, on the nature and yield of metalliferous deposits, has just been published. Descriptions are given of the principal ore deposits of the world, and the statistics of production appended furnish a clear idea of the condition of the mining industry at the present time. The I Alessandro Barca, "Sulla Scomposizione dell' alcali flogisticato" (Cpusc. Scelti vii. ${ }^{783}$ ).

"Anton M. Vassalli, "Parallelo della Luce Sulare e di quella della combustione" (Opusc. Scelti xvii. 1794, p. 1 $\infty$ ).

NO. I 6 I 8 , VOL. 63 ] subject is of grcat importance from a commercial point of view, as will be evident from a moment's consideration of the enormous value of mineral resources. In the Lnited Kingdom alone, the value of the minerals raised in one year has approached $80,000,000 \%$; and the vast sums representing the British capital invested in mines in all parts of the world will be readily appreciated. Last year, the number of new mining companies registered in Great Britain was 559, with a united nominal capital of $71,687,366 l$. Of these companies, 281 , with a nominal capital of $37,037,057 l$, were formed to mine and explore in British colonies and dependencies, and 157, with a nominal capital of $24,049,502 l$., to mine in foreign countries. During the present century the mining industry has made remarkable strides. Some indication of the progress made, even during the past ten years, is afforded by a comparison of the world's output of metals in 1889 and in I 898 . In round numbers, the production of the principal metals was as follow's :-

\begin{tabular}{|c|c|c|c|c|c|c|}
\hline & & $\begin{array}{l}18.0 \% \\
\text { lions. }\end{array}$ & & $\begin{array}{l}1^{8} 98 . \\
\text { Tons. }\end{array}$ & & $\begin{array}{c}\text { Value of out- } \\
\text { put in } \times 8993 \text {. } \\
6\end{array}$ \\
\hline & $\cdots$ & $26,000,000$ & $\ldots$ & $36,000,000$ & .. & $100,000,000$ \\
\hline & $\ldots$ & 182 & $\ldots$ & $43^{\circ}$ & $\ldots$ & $57,500,000$ \\
\hline & $\ldots$ & 3,900 & $\ldots$ & 6,000 & $\ldots$ & $24,000,000$ \\
\hline er... & $\ldots$ & 266,000 & $\ldots$ & $431, \infty 00$ & $\cdots$ & $21,75^{\circ}, 000$ \\
\hline$\ldots$ & $\ldots$ & 549,000 & $\ldots$ & & $\ldots$ & $10, \infty 00,000$ \\
\hline $\mathrm{Zit}$ & $\ldots$ & 335,000 & $\ldots$ & 468,000 & $\cdots$ & soo \\
\hline & $\ldots$ & 55 & $\ldots$ & 77,000 & $\cdots$ & $, \infty 00, \infty 00$ \\
\hline An & $\ldots$ & $\infty$ & $\ldots$ & 000 & $\cdots$ & $, 100,000$ \\
\hline & $\ldots$ & & $\ldots$ & 4,100 & $\ldots$ & 8 I 5,000 \\
\hline & 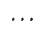 & 1,830 & $\cdots$ & 6,200 & $\cdots$ & 725,000 \\
\hline Aluminium & & 70 & $\ldots$ & 4,000 & $\ldots$ & 440,000 \\
\hline
\end{tabular}

The simplest classification of the ore deposits from which these vast outputs have been obtained, divides them into (I) beds, (2) veins, and (3) masses. This classification has proved well adapted for practical use. The more elaborate systems of classification that have from time to time been proposed are fully discussed, the classifications dealt with being those of Agricola (1555), Burat (1855), B. von Cotta (1853), Grimm (1869), J. A. Phillips (1884). A. von Groddeck (1878), F. Pošepný (1880), Sir A. Geikie (1882), H. S. Monroe (1892), II. F. K $\mathrm{cmp}(1892)$, II. Louis (1896), H. Hoefer (1897) and G. Gitrich (1899). The last-named investigator uses the mode of concentration as the basis of classification. The concentration may take place with or without a change in the state of aggregation. In the former case the passage into the solid state is from a state of vapour, from a molten state, or from a state of aqueous solution. Consequently the following classes of ore deposits are distinguished :-

I. Sublimation deposits: $(a)$ syngenetic, in which the sublimation of the vapours takes place simultaneously with the solidification and within a solidifying magma, e.g. tin ore deposits; (b) epigenetic, in which crusts are formed coating fissures; (a) metagenetic, in which the constituents of a rock are dissolved by pneumatolysis and replaced by metailic substances.

II. Magmatic, or solidifying deposits : $(a)$ syngenetic, repre. senting the usual form of magmatic deposit as described by Vogt; (b) epigenetic, only imaginable if an apophysis of a magma within the enclosing rock consists of a metallic band; (c) metagenetic, hardly imaginable.

III. I'recipitation deposits : $(a)$ syngenetic, in which the chemical precipitation takes place simultaneously with the sedi. mentation, the deposit being formed simultaneously with the surrounding rock, e.g. seams, beds; (b) diagenetic, in which the concentration takes place in the nuddy floor of a lake, e.g. concretionary nodules of clay iron ore; $(c)$ epigenetic, in which the deposit is formed subsequently to the surrounding rock, e.g. veins, cave fillings; (d) metagenetic, in which the soluble constituents of a rock are dissolved, transported, and the metallic substance precipitated, the deposit being formed subsequently to the enclosing rock, but growing at the expense of the latter.

IV. Separation deposits: (a) residual deposits formed by chemical concentration, a soluble rock constituent, e.g. lime, being carried away, and a metallic substance, e.g. brown iron ore, remaining unaltered; (b) detrital deposits formed by mechanical concentration, e.g. dry placers, alluvial deposits.

In view of the apparent impossibility of definitely determining the genesis of a given deposit, it may be questioned how far it is advisable to adopt a genetic classification. Probably, however, by employing that system of classification, an observer would be induced to make a more thorough examination than if he were 